\title{
Dynamic conservation of variability: responses of wheat populations to different selective forces including powdery mildew
}

\author{
V Le Boulc'h ${ }^{1,2}$, JL David ${ }^{1}$, P Brabant ${ }^{1,3}$, \\ C de Vallavieille-Pope ${ }^{2}$ \\ 1 Institut National de la Recherche Agronomique-UPS, Station de Génétique Végétale, \\ Ferme du Moulon, 91190 Gif-sur-Yvette; \\ 2 Institut National de la Recherche Agronomique, Laboratoire de Pathologie Végétale, \\ Grignon, 78850 Thiverval-Grignon; \\ 3 Institut National Agronomique Paris-Grignon, 16, rue Claude-Bernard, \\ 75005 Paris, France
}

\begin{abstract}
Summary - A programme of dynamic conservation of genetic resources has been conducted on winter wheat in France since 1984. One allogamous and 2 preferential selfing populations, with a large genetic base, made up the initial gene pools. Seed samples of these pools were distributed throughout a multi-site experimental network. The populations obtained were multiplied each year in each site. Populations developed significantly after 8 years of multiplication: plant height had increased, the proportion of viable pollen grains had increased in male-fertile plants of allogamous populations and a north-south gradient for precocity was observed for autogamous populations. Resistance to powdery mildew had developed in local populations, both for adult-plant resistance and the frequency of specific resistance genes to Erysiphe graminis f sp tritici. The differentiation depended on the gene pool of the host populations. Virulence frequencies of the parasite populations varied according to the site and the year. There was no clear relationship between virulence frequencies and resistance gene frequencies. The proportion of plants without specific resistance genes seems to correlate with adult-plant susceptibility in local autogamous populations. Most of the variability was maintained through propagation under various natural selection forces.
\end{abstract}

dynamic conservation / Triticum aestivum / Erysiphe graminis / natural selection / population

Résumé - Gestion dynamique de la variabilité : réponses de populations de blé tendre à différentes forces sélectives dont l'oüdium. Un programme de gestion dynamique des ressources génétiques est développé en France depuis 1984 sur le blé tendre. Deux populations préférentiellement autogames et une popuiation conduite en allogamie, toutes 3 à large base génétique, constituaient les pools génétiques de départ. Des échantillons 
de grains de ces pools ont été distribués dans un réseau multilocal. Les populations ainsi obtenues sont multipliées année après année dans chaque lieu du réseau. Après 8 ans de multiplication, les populations ont nettement évolué. On constate une augmentation de la taille des plantes adultes, une meilleure production de grains de pollen viable chez les plantes mâles fertiles des populations allogames et la mise en place d'un gradient de précocité Nord-Sud pour les populations autogames. La résistance à l'oïdium a évolué dans les populations, à la fois pour la résistance au stade adulte et pour les fréquences de gènes de résistance spécifique vis-à-vis $d$ 'Erysiphe graminis $f s p$ tritici. La différenciation dépend du pool génétique auquel appartiennent les populations hôtes. Les fréquences de virulence des populations du parasite varient selon les sites et les années. Aucune relation claire n'a été mise en évidence entre les fréquences de virulences du parasite et celles des gènes de résistance spécifique de l'hôte. La proportion de plantes sans résistance spécifique semble corrélée à la sensibilité au stade adulte dans les populations autogames. La diversité des milieux formant le réseau a globalement permis le maintien de la variabilité.

gestion dynamique / Triticum aestivum / Erysiphe graminis / sélection naturelle / population

\section{INTRODUCTION}

The conservation of the genetic diversity of cultivated species enables us to maintain selected genes involved in a plant's adaptation to different environments. The management of genetic resources by storing seed samples $e x$ situ is a widely used method, which answers an urgent problem of conserving the genetic diversity of a species but only represents one aspect of conserving genetic resources. It does, however, have limitations:

- the number of samples to be conserved is very large and continues to increase;

- evaluation of seed samples is costly and can only be carried out for a limited number of traits and samples. A major part of the variability stored is therefore poorly known;

- the variability stored is isolated from the evolution of the natural environment.

The dynamic management of populations maintained in their natural environment has often been proposed as complementary to static management (Pernès, 1984; Allard, 1990, Henry et al, 1991). Its objective is to imitate nature in its ability to maintain a wide variability within numerous small diversified populations. Humankind has played an important role in diversifying and spreading cultivated species over huge territories; this activity should therefore be envisaged in a dynamic conservation programme aimed at maintaining resources which can be used in plant breeding (Gallais et al, 1992).

In order to establish a methodology for dynamic conservation and to evaluate its potentials, a programme was set up on a national scale under the impetus of the Institut National Agronomique of Paris-Grignon using genetic material selected by INRA. Since 1984, INRA and a number of agricultural universities and schools have participated in a network for the multiplication of winter wheat populations (Triticum aestivum L) (Henry et al, 1991). Three different populations, PA0, PB0 and PSO, constituted the initial gene pools. PAO and PBO were obtained from a 
pyramidal cross involving 16 parents representing a wide genetic base. PS0 was obtained from a cross of 50 lines with the male-sterile variety Probus, which is homozygous for the recessive gene $m s 1 b$ of the nucleus (Trottet, 1988). Seed samples from these pools were distributed throughout sites representing a varied range of environments. The populations obtained in this way were multiplied and resown year after year in the same site. To increase the diversity of environmental conditions, populations were grown in each site using both an intensive farming method (with the same nitrogen fertilizers and pesticides as those used in the region) and an extensive farming method (one third of the nitrogen fertilizers used in the intensive method and fewer pesticide treatments). This structure was chosen to enable the local differentiation of each population, while maintaining a large genetic variability throughout the network (David et al, 1992). The populations obtained from PAO and PBO are preferential selfing populations and those obtained from PS0 are outcrossed using male sterility. The objective was to measure the value of outcrossing an autogamous species to conserve its genetic diversity. Precise descriptions of the 3 populations and how they were obtained were provided by Picard (1984), Thomas et al (1991) and Pontis (1992).

The first results (David, 1992; Pontis, 1992) showed that a very distinct differentiation between subpopulations of the same origin (PA, PB or PS) appeared after only a few years of multiplication. Genetic drift could not be ruled out to explain this, but such a rapid differentiation would only be expected if the number of reproductive individuals was small, which was not the case with the experimental protocols used (Pontis, 1992). Selection appeared to be the most likely cause of the observed developments, either directly or by hitch-hiking. There are at least 3 types of selection pressures in our experiment:

- intrinsic pressures, which are the result of interactions between individuals within each subpopulation;

- pressures imposed by the external physical (pedoclimatic) conditions;

- pressures resulting from the interaction of other biotic factors such as pathogens.

After briefly considering the evolution observed in traits subjected to the first 2 types of selection pressures, we will present in detail the results concerning the evolution of resistance to powdery mildew (Erysiphe graminis DC ex Merat f sp tritici Em Marchal).

\section{Selection forces intrinsic to populations: the evolution of plant size and pollen production}

In a genetically heterogeneous population, competition between individuals creates selection forces which change depending on the genetic structure of the population and the environmental conditions. The experiment conducted on winter wheat provided 2 examples of evolution under the influence of inter-genotype competition. The first example concerns the evolution of plant size. The second concerns pollen production in the PS allogamous pool.

A general increase in adult plant height was observed in all the populations originating from the PA and PB autogamous pools (David, 1992). The tall plants gradually eliminated short plants. Competition for light among plants of varying sizes appeared to be the main driving force behind this evolution. Goldringer et al 
(1994) showed in the PB population that the tall lines were favoured in competitive situations with short lines. Their seed production is higher when in competition than in monoculture. For short lines, the opposite phenomenon has been observed: they produce more in monoculture than in a competitive situation with taller plants. The evolution observed in our experiment was greater and more rapid than that observed in the United States in barley populations under comparable growing conditions (Hockett et al, 1983; Allard, 1988). This difference in behaviour is due to the genetic composition of the wheat populations: the initial 1984 populations contained 2 dwarfing genes (rht1 and rht2, McIntosh, 1988) at relatively high frequencies (Pontis, 1992). The differences in size between genotypes was therefore very distinct and moreover very heritable. Figure 1 shows the relationship between the average size of adult plants within the populations and the frequency of individuals with dwarfing genes. This situation enabled a rapid evolution of plant height and a drop in the frequency of the rht1 and rht2 genes. The rapidity of the phenomenon can also be explained by the increasingly greater proportion of tall plants. Indeed, the more tall plants there are, the more the short plants are disadvantaged.

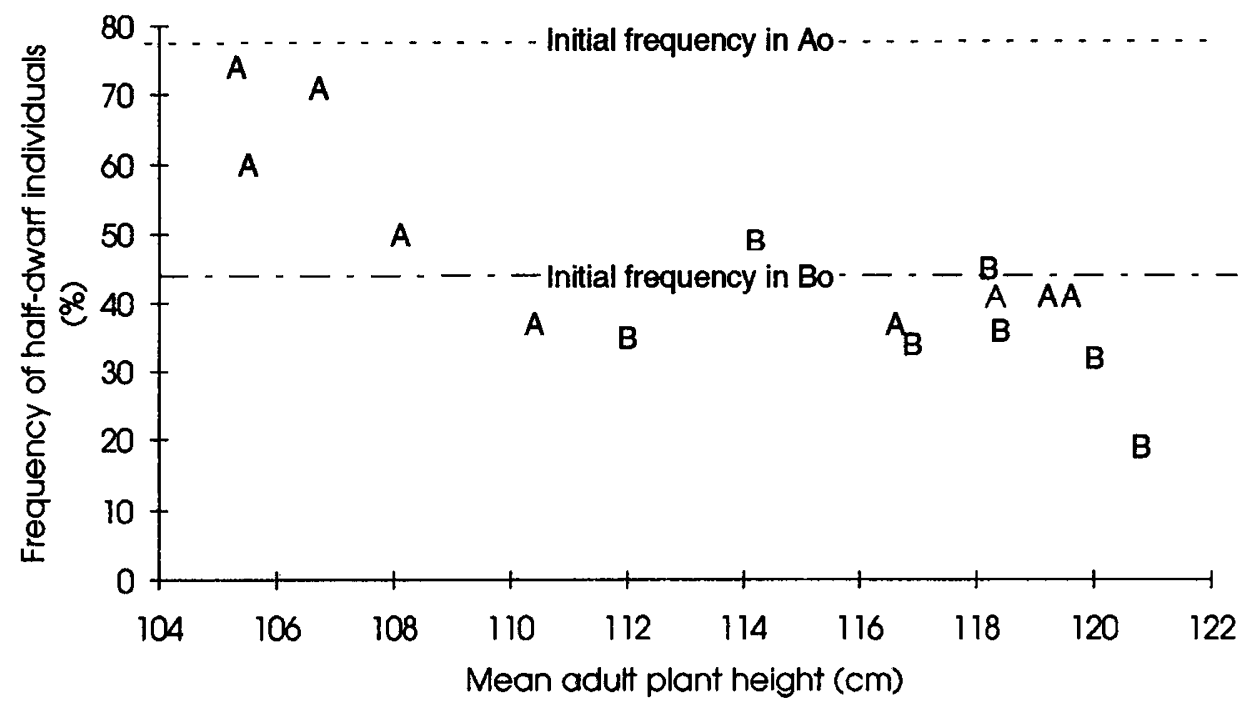

Fig 1. Relationship between adult plant mean height and half-dwarf frequency in the wheat populations of the 1988 generation. Each point corresponds to the average of about 200 plants of a pool A or a pool B population. The half-dwarf individual frequency was obtained by treating seed samples of these populations with gibberellic acid. The individuals that were insensitive to this hormone (with rht1 and/or rht2 genes) did not grow as tall as control plants. Individuals were assessed $10 \mathrm{~d}$ after germination. Adult plant height was recorded in the field on a different seed sample of the same generation (Pontis, 1992). A: pool A population; B: pool B population; $\mathrm{A}_{\mathrm{o}}$ : initial population of pool $A ; B_{0}$ : initial population of pool $B$.

Despite the general tendency for the size to increase, there were differences between the average heights of the different populations in the dynamic conservation programme (David, 1992). This may be due to the variable intensity of competition 
depending on environmental conditions: rainfall, nitrogen dose, and soil depth. For example, nitrogen increases the intensity of competition, first by enabling dense plantations to be established and second by allowing substantial growth in height. Therefore the autogamous populations PA and PB grown intensively became genetically taller than the populations grown extensively.

At present, it is not known just how far the programme can increase the height of wheat populations. Very tall plants $(1.8 \mathrm{~m})$ were observed which did not exist in the initial populations but which were obtained by recombination. Plant height of adult wheat grown in bulk is considered to be a trait subject to stabilizing selection (Khalifa and Qualset, 1975), the shortest being eliminated by competition and the tallest by lodging. Lodging may also favour tall plants since they remain above the plant cover, continue to capture light and stay in a satisfactory state of health.

This evolution in height is a problem if we wish to maintain genetic diversity for subsequent exploitation. Modern varieties are genetically more productive because they produce a higher grain weight for the same aerial biomass (Austin et al, 1989). This evolution occurred because of the decrease in the length of stems. Small size is also an adaptation to the intensive growing practices which involve greater plantation densities and high levels of fertilization.

In addition to the problem of time involved in converting tall genotypes to cultivable genotypes, losing dwarfing genes in populations would be an error, since they have numerous pleiotropic effects (Pinthus and Gale, 1990). It is therefore necessary that populations evolve with these genes in order to select an adapted gene pool. Height is also a physical means of escaping from certain pressures from parasites, particularly on the spike (Septoria nodorum, Scott et al, 1985). This phenomenon, in uniformly tall populations, prevents selecting other genetic resistance mechanisms which would function in short varieties.

A second example of competition between individual plants is provided by the evolution observed in pollen production with the allogamous PS gene pool. Wheat is naturally autogamous and produces relatively little pollen. Introducing allogamy in the species creates a major disturbance. In PS, the reproductive value of hermaphrodite plants depends solely on their capacity to fertilize females. They are used as males and these males compete with each other in their ability to pollinate. Theoretically, their viable pollen production is expected to improve (Charnov, 1982). In fact, this improvement was observed 6 years after the beginning of the experiment (David and Pham, 1993). Selection pressure on this trait is strong and can result in modifications of morphological and developmental traits which also have a role in adapting the plant to environmental conditions.

Competition phenomena among plants are a major factor in population evolution. When they are present, the evolutionary response is expected to be directional, but with differences in intensity depending on the environments in which the populations are multiplied. Difficulties arise in conserving diversity for genes subjected to these selection forces.

\section{Selection for adaptation to the physical environment}

The evolutionary pressures exerted by the environment can be considered as relatively constant and independent of the genetic structure of the populations. 
Under these conditions, populations are expected to differentiate in order to adapt to the characteristics of their environment. Contrary to the example of interindividual competition, the evolution may occur in directions radiating around the initial situation. This idea is at the basis of the concept of the centre of origin (Pernès, 1984); the diversity of environments creates and maintains genetic diversity. This also justifies the dynamic conservation of diversity. This means that it is possible to recreate or restructure a lost natural variability by subjecting a genetically heterogeneous population to a particular environment; the adaptative responses are expected to be repeatable.

For the autogamous populations of the PA and PB pools, we observed a north/south gradient for precocity. The populations multiplied in the south became genetically more precocious than those multiplied in the north (fig 2). This evolution was presumably an adaptation to the environment firstly because the trend occurred in numerous independent populations and secondly because of the reproductive cycle of the plant. In the south, water stress appears early and late plants do not fill their seeds satisfactorily. These seeds are scalded and are at a selective disadvantage. In the north, this stress never appears or else appears late. Late plants accumulate more dry matter and can be more productive. More generally, this phenomenon can also be due to an adaptation to the length of the day, variable on the north/south axis. A gradient for north/south precocity has also been found for old wheat cultivars on a regional scale going from the Middle East through to Nepal (Kato and Yokoyama, 1992).

In autogamous populations, it seems that a large part of inter-population variability is caused by an adaptation to the environment and this applies to multiple traits (Weir et al, 1974; Mitchell-Olds, 1992; Nevo and Beiles, 1992; Oosterom and Acevedo, 1992). It may therefore be possible to use environmental variations for conserving genetic resources.

\section{An adaptative response to the biotic environment}

Selection pressures due to parasites are caused by genetically variable living organisms. Parasites evolve in interaction with host plants and exert variable selection pressures which depend on the location, and evolve with time, as shown by the French populations of Erysiphe graminis f sp hordei (Andrivon and de Vallavieille-Pope, 1993). These pressures involve a system of coevolution between 2 types of population, host populations and pathogen populations. In barley populations in California, Allard (1990) observed a positive correlation between an increase in the frequency of resistance alleles and their selective advantage towards the parasite population Rhynchosporium secalis.

Resistance to powdery mildew is a good marker, since it is a very widespread disease causing considerable reductions in yield. Moreover, powdery mildew is caused by a biotrophic parasite which has a very specific relationship with its host, without a saprophytic phase. Resistance to powdery mildew in wheat has 2 components: specific resistance in accordance with the gene-for-gene model described by Flor (1955), and a general resistance, whose genetic bases are poorly known. The resistance of adult plants in the field is the result of these 2 components.

First we will present the results of a study of pathogen populations, present in 3 sites of the network. In order to evaluate the heterogeneity of the selection 


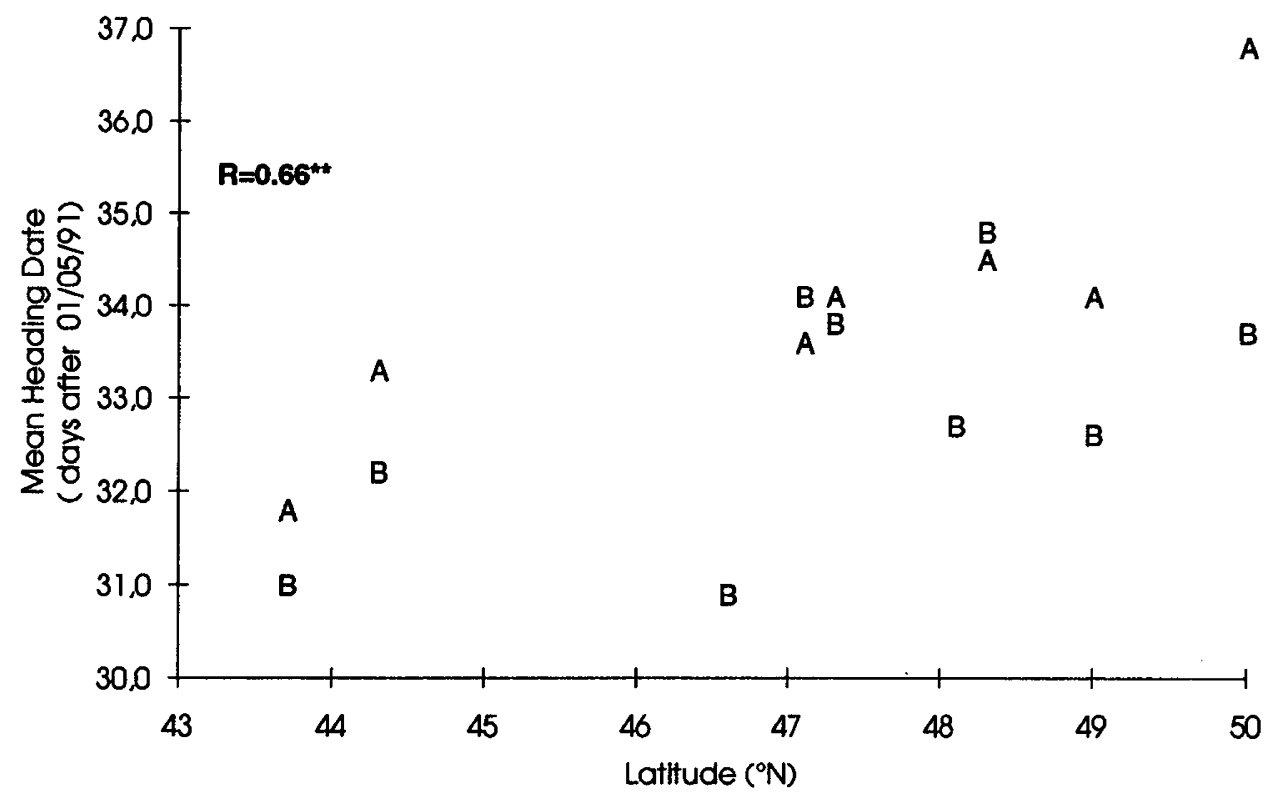

Fig 2. Heading date differentiation in wheat populations according to the latitude of their multiplication site. The populations were assessed at Le Moulon (Gif-sur-Yvette, $48^{\circ} 9^{\prime} \mathrm{N}$ ). Each point corresponds to the heading date average of the 2 populations grown in the same site by intensive or extensive cultivation methods. The regression coefficient $(R)$ was calculated using total populations $\left({ }^{* *} P<1 \%\right)$. A: pool A population; B: pool B population.

pressures due to parasites, we characterized the virulence spectra of these populations for some known genes. Second, the frequency of several resistance genes was estimated in plant populations multiplied on the same sites, harvested after 8 years of evolution. In these populations, each plant was different and resistance genes were determined for each individual: this was an original approach. Finally, resistance at the adult stage of these populations was estimated in the field.

\section{MATERIALS AND METHODS}

\section{Virulence spectra of the pathogen populations}

Virulence frequencies in $E$ graminis $\mathrm{f}$ sp tritici populations were estimated for 3 sites of the multiplication network, Le Moulon (Gif-sur-Yvette), Le Rheu (near Rennes) and Toulouse, for 1991 and 1992. The frequencies were determined using seedlings of differential hosts (table I), which were placed in the 3 sites to trap pathogen population spores.

Each set of differential hosts included 10 plants of each line, with the primary leaf fully developed, grouped together in a $6 \times 6 \mathrm{~cm}$ pot. For each site, 2 differential host sets were placed near 2 populations grown by extensive methods (PA and 
Table I. Differential host set.

\begin{tabular}{llll}
\hline Differential lines & Resistance genes & Differential lines & Resistance genes \\
\hline Axminster & $P m 1$ & Michigan & $M i a^{*}$ \\
Ulka & $P m 2$ & Talent & $T a l^{*}$ \\
Asosan & $P m 3 a$ & TPl14 & $P m 2+P m 6$ \\
Chul & $P m 3 b$ & Hornet & $P m 2+P m 8$ \\
Sonora & $P m 3 c$ & Kronjuwel & $P m 4 b+P m 8$ \\
Khapli & $P m 4 a$ & Maris Dove $_{4}$ & $P m 2+M l d$ \\
Armada & $P m 4 b$ & Brock $^{\mathrm{a}}$ & $P m 2+T a l^{*}$ \\
Hope & $P m 5$ & Mission $^{\text {a }}$ & $P m 4 b+M l i$ \\
Transec & $P m 7$ & Mercia & $M l i+T a l^{*}$ \\
Clément & $P m 8$ & Mephisto & $P m 1+P m 2+P m 9$ \\
Amigo & $P m 17^{*}$ & Rendez-vous & $P m 2+P m 4 b+P m 6$ \\
Courtot & $P m a r^{*}$ & Apollo & $P m 2+P m 4 b+P m 8$ \\
Aquila & a & Crossbow & $P m 2+P m 6+M l i$ \\
Syros & $M l k$ & Axona & $P m 2+M l d+M l k^{*}$ \\
\hline
\end{tabular}

Data from McIntosh, 1988; McIntosh et al, 1989, 1990. ${ }^{\text {a }}$ Lines present only in the 1992 experiment. ${ }^{*}$ Doussinault, personal communication (the Tal gene provides partial resistance).

PB for Le Moulon and Toulouse, and PB and PS for Le Rheu) and were left for 1 d. For each differential set, the lines were placed at random. In order to have 2 replications for Le Moulon and Le Rheu, 2 differential host sets were placed close to each population. The experiment was repeated twice per season, in the first days of May and June.

After a $10-\mathrm{d}$ incubation period at $20^{\circ} \mathrm{C}$ protected from any outside infection, sporulating lesions were counted on the primary leaf of the plants in each differential host set. The frequency of each virulence gene (or virulence gene combination) was estimated from the infection rate on the corresponding differential line, which was the ratio between the number of lesions on this line and the number of lesions on the most infected differential line.

ANOVA was used for statistical analysis; preliminary tests showed that 'year', 'site' and 'differential line' effects and interactions on infection rates were highly significant. The effects of the date of the experiment and the population in proximity to the differential host set were not significant $(P>5 \%)$. Consequently, we present the results for each line per site and per year, the infection rates being averaged over the season.

\section{Evolution of specific resistance genes}

We studied 12 resistance genes, the $P m 1$ to $P m 6$ series, $P m 8, M l i$ and the Michigan cultivar gene (Mia), which are the most commonly used in breeding programmes. In order to detect these genes in plants, we selected a monocolonial isolate collection with virulence patterns adapted to identifying the 12 genes. Among 50 isolates tested initially, 9 were retained (annex 1) to make up the collection but $\operatorname{Pm} 6$ was not detected and did not identify all the genes studied separately. The following 
genes were indissociable: $P m 4 a$ and $P m 4 b ; P m 3 c, P m 5$ and $M i a$. In addition, some tests were unable to distinguish $M l i$ from $P m 8$. These indeterminations will be referred to as $P m 4 a / P m 4 b, P m 3 c / P m 5 / M i a$ and $M l i / P m 8$.

For each of the PA, PB and PS pools, analyses were conducted on the populations grown for $8 \mathrm{yr}$ at Le Moulon, Le Rheu and Toulouse (1992 harvest) and on the populations PB0, PS0 and PA1. Because of the low germination capacity of the initial population PA0, we used the population PA1 grown for 1 yr at Le Moulon and harvested in 1985 as the reference for pool $\mathrm{A}$.

Between 40 and 75 plants were analysed per population. To identify resistant genes in individual plants, each plant was inoculated with the 9 isolates according to the method described by Limpert (1985). The first 2 leaves were cut into 9 segments and each segment was inoculated separately with 1 isolate. Sporulation was observed after a 10-d incubation period in a mildew-proof growth chamber at $16^{\circ} \mathrm{C}$.

\section{Evolution of adult plant resistance}

An experimental study of adult plant resistance to powdery mildew was conducted at Le Moulon. It included the initial populations PB0 and PS0 and populations of the 3 pools A, B, and S grown for $6 \mathrm{yr}$ at Le Moulon, Le Rheu and Toulouse (1990 harvest). The experimental design was a randomized block with 2 replications and 50 plants in each plot. Plants were scored individually twice (once at the end of May, and once at the end of June). A 0 -to- 9 scale was used with 0 for a plant without visible symptoms and 9 for a plant with a high density of sporulating pustules up to the last leaf.

\section{RESULTS}

\section{Virulence spectra of the pathogen populations}

The infection rates of each differential line for 1991 and 1992 at Le Moulon, Le Rheu and Toulouse were determined (fig 3). At Le Moulon in 1991 many virulence genes were present in the pathogen population, since only $P m 3 b$ virulence and the $P m 2+$ $M l d+M l k$ virulence combination had low frequency. From 1991 to 1992, frequencies of several virulence genes decreased. Only $P_{m} 3 b$ frequency clearly increased.

Numerous virulence genes were also present at Le Rheu. There was very little difference between the $2 \mathrm{yr}$. In particular, the frequency of $P m 17, P m 3 b, P m 3 a, M l k$ and $P m 2+M l d, P m 2+M l d+M l k$ combinations remained very low. Compared with Le Moulon, the pathogen population of Le Rheu had more combinations of several virulence genes, except those with $P m 6$ or Tal.

The results from Toulouse were considerably different from those of the 2 other sites, because there were few virulence genes at high frequency in the pathogen population, particularly in 1992 .

The correlation matrix, established from common differential hosts for the $2 \mathrm{yr}$ (table II), shows the overall differences between sites and years. The 1991 and 1992 spectra of the Le Rheu pathogen population are clearly similar $(0.97$ correlation coefficient). Between-year correlation is lower for the other 2 sites (0.73 in Le 


\begin{tabular}{|c|c|c|}
\hline $\begin{array}{l}\text { present in } \\
\text { differential host }\end{array}$ & LEMOUL & \\
\hline Pm4a & 98 & $\| \mathrm{Pm} 7$ \\
\hline $\mathrm{Pm} 7$ & & Pm4a \\
\hline Mia & $8 / 2$ & Pm4b \\
\hline Pm4b & 85 & Pm2 \\
\hline Mll+Tal & 79 & Pm8 \\
\hline Pm2 & & Pml \\
\hline $\mathrm{Pml}$ & & $P m 4 b+P m 8$ \\
\hline $\mathrm{Pm} 3 \mathrm{c}$ & & Tal \\
\hline Tal & 69 & $\mathrm{Pm} 2+\mathrm{Pm} 8$ \\
\hline Pms & 64 & $\mathrm{Pm} 2+\mathrm{Pm} 4 \mathrm{~b}+\mathrm{Pm}$ \\
\hline Pm5 & & Mili+Tal \\
\hline$P m 2+P m b$ & 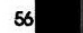 & $\mathrm{Pm} 2+\mathrm{Pm} 6$ \\
\hline $\mathrm{Pm} 17$ & 5 & Mia \\
\hline$P m 4 b+P m 8$ & 5 & $\operatorname{Pm} 3 \mathrm{c}$ \\
\hline $\mathrm{Pm} 2+\mathrm{Pm} 8$ & 51 & Pml+Pm2+Pm9 \\
\hline$P m 2+P m 4 b+P m 6$ & 49 & Pm5 \\
\hline$P m 2+P m 4 b+P m 8$ & & $P m 2+P m 4 b+P m e$ \\
\hline Mik & 43 & Pm17 \\
\hline Pm3a & 39 & Pm2+Mld \\
\hline Pm2+Mld & 28 & Pm3b \\
\hline$P m l+P m 2+P m 9$ & $2 6 \longdiv { 2 0 }$ & Pm3a \\
\hline Pm3b & & Mik \\
\hline$P m 2+M l d+M I k$ & 25, & Pm2+Mld+Mik \\
\hline
\end{tabular}

LE RHEU

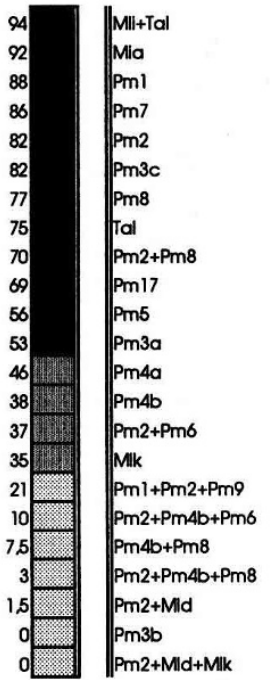

1992

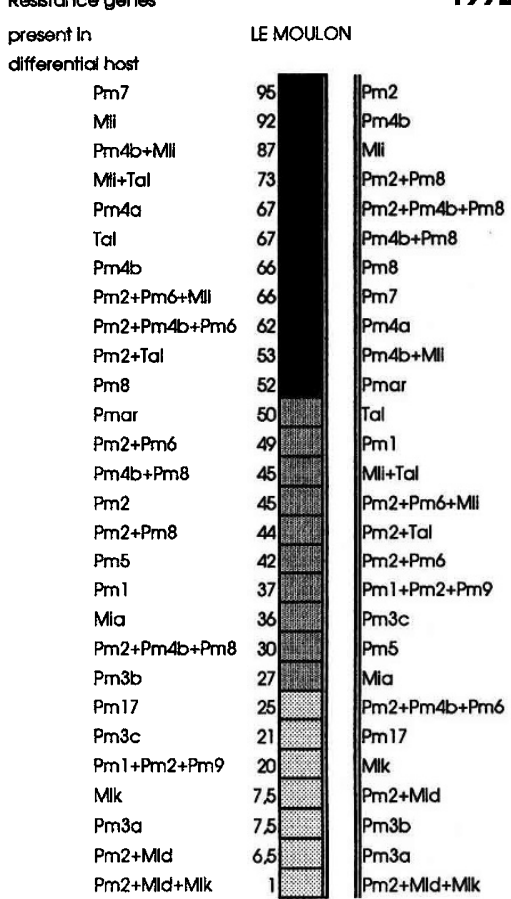

LE RHEU

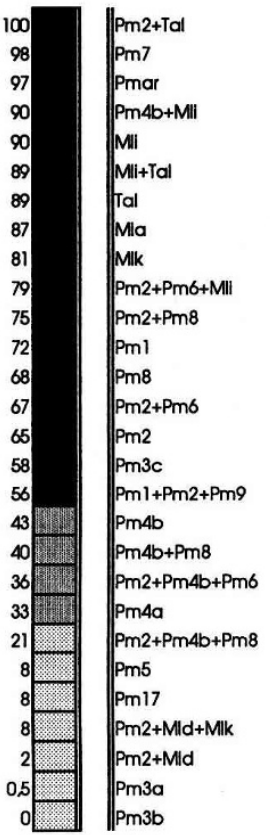

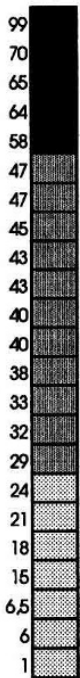

TOULOUSE

TOULOUSE

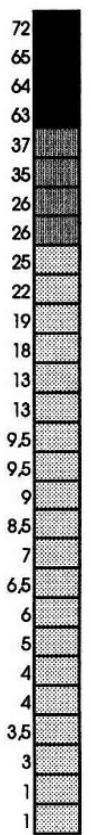

Fig 3. Virulence spectra of Erysiphe graminis f sp tritici populations in the locations of Le Moulon, Le Rheu and Toulouse in 1991 and 1992. The frequency of each virulence gene was determined from the number of sporulating lesions on the primary leaf of 10 plants for each differential host. The frequency (in \%) was estimated from the ratio between the number of lesions on each differential line and the number of lesions on the most infected differential line. Results are presented per site and per year. 
Moulon and 0.63 in Toulouse). The correlations between spectra of the Le Rheu and Toulouse pathogen populations are the lowest between-site correlations $(0.45$ for 1991 and 0.33 for 1992). For Le Moulon and Toulouse, the differences between the years are comparable to the differences between the sites: 'Within-site betweenyear' correlations are close to 'between-site within-year' correlations.

Table II. Linear correlation coefficients between virulence spectra of Erysiphe graminis $\mathrm{f}$ sp tritici in the experimental sites of Le Moulon, Le Rheu and Toulouse in 1991 and 1992.

\begin{tabular}{lllllll}
\hline & $\begin{array}{c}\text { Le Moulon } \\
91\end{array}$ & $\begin{array}{c}\text { Le Moulon } \\
92\end{array}$ & $\begin{array}{c}\text { Le Rheu } \\
91\end{array}$ & $\begin{array}{c}\text { Le Rheu } \\
92\end{array}$ & $\begin{array}{c}\text { Toulouse } \\
91\end{array}$ & $\begin{array}{c}\text { Toulouse } \\
92\end{array}$ \\
\hline Le Moulon 91 & 1 & & & & & \\
Le Moulon 92 & $0.73^{* * * *}$ & 1 & & & & \\
Le Rheu 91 & $0.74^{* * * *}$ & $0.75^{* * * *}$ & 1 & & & \\
Le Rheu 92 & $0.63^{* *}$ & $0.69^{* * *}$ & $0.97^{* * * *}$ & 1 & & \\
Toulouse 91 & $0.75^{* * * *}$ & $0.52^{*}$ & $0.45^{*}$ & 0.38 & 1 & \\
Toulouse 92 & $0.54^{* *}$ & $0.60^{* *}$ & 0.40 & 0.33 & $0.63^{* *}$ & 1 \\
\hline
\end{tabular}

Coefficients calculated on the reaction to Erysiphe graminis $\mathrm{f}$ sp tritici of 23 differential lines. ${ }^{* * *} P<0.01 \%$; ${ }^{* * *} P<0.1 \% ;{ }^{* *} P<1 \%$; ${ }^{*} P<5 \%$.

\section{Evolution of specific resistance genes}

In the population set (table III), $P m 1, P m 2, M l i, P m 8$ genes and $P m 4 a / P m 4 b$ and $M l i / P m 8$ were identified. $P m 3 b$ was considered to be present only in pool A and $P m 3 c / P m 5 / M i a$ only in pool S. Other resistance genes may have been present, but our experiment did not detect them.

In pool B, the only significant difference (at $P<10 \%$ ) between 1992 populations and the initial population is the increase in the frequency of susceptible plants in the population of Le Rheu. In contrast, populations of pools A and S had evolved. For pool A, frequencies increased for Pm2 and $M l i$ in Le Rheu, and for $M l i / P m 8$ in Toulouse. For pool S, an increase of $P m 4 a / P m 4 b$ frequency was observed in the 3 sites. $(P<5 \%$ in Le Rheu and Toulouse, but $P<10 \%$ in Le Moulon). Overall, the populations of Le Moulon evolved less than the populations of Le Rheu and Toulouse.

To evaluate the total evolution of each pool, we compared the frequency of susceptible plants in the initial population to the average in the 3 descendant populations. We noticed a highly significant decrease $(P<1 \%)$ in PS and a small decrease $(P<10 \%)$ in PA. The mean increase in PB was not significant.

Figure 4 shows the evolution of the gene combinations detected in the experiment. In pool A, combinations of 3 genes appeared in Le Rheu and Toulouse. For pool B, combinations of 2,3 and 4 genes were identified whereas they were absent in PB0. In pool S, the Le Moulon and Toulouse populations showed complex combinations, with probably more than 4 genes, which were absent in PSO. On the other hand, in the same pool, the population of Le Rheu possessed, at most, double resistant plants. Apart from the Le Rheu population, the populations of the 3 pools 


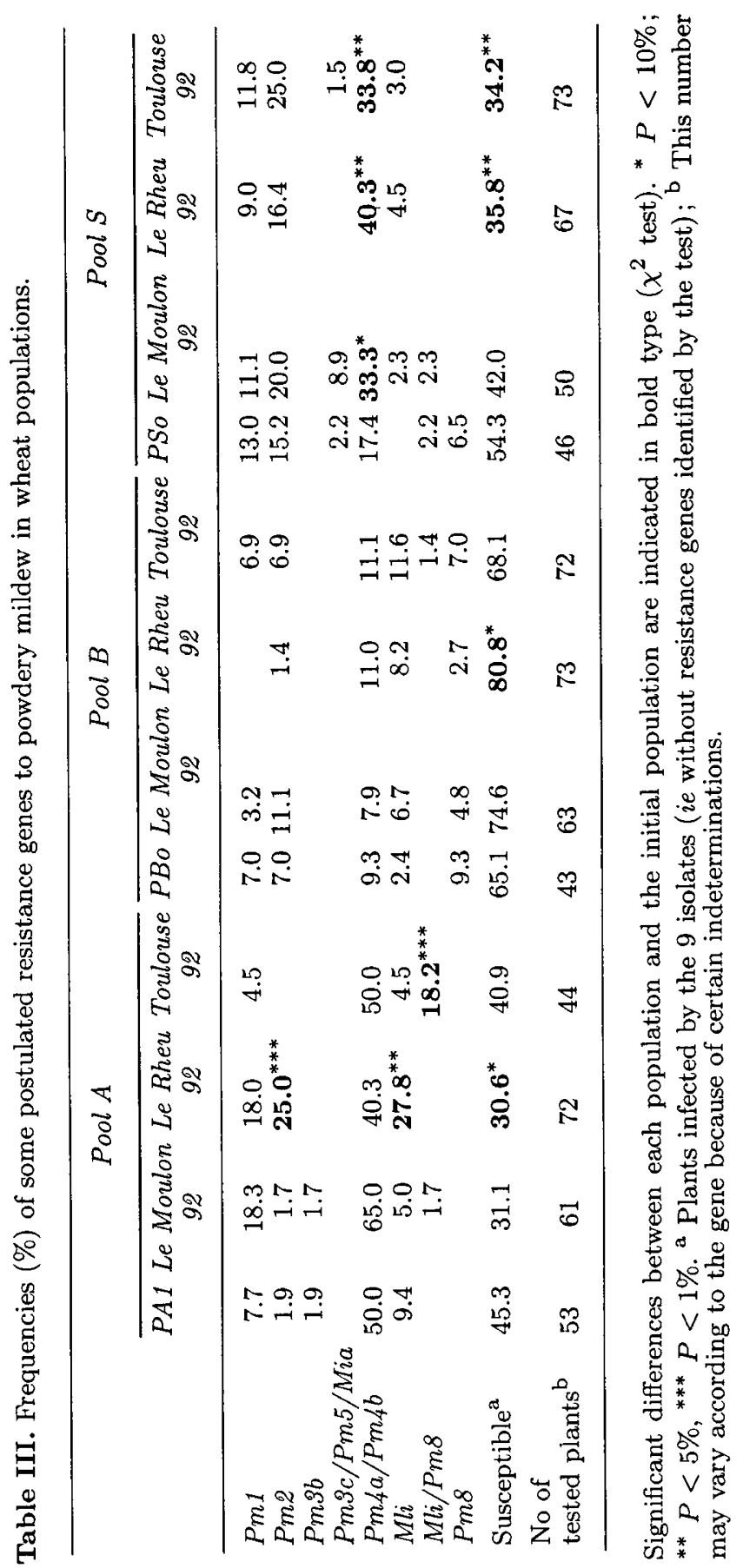




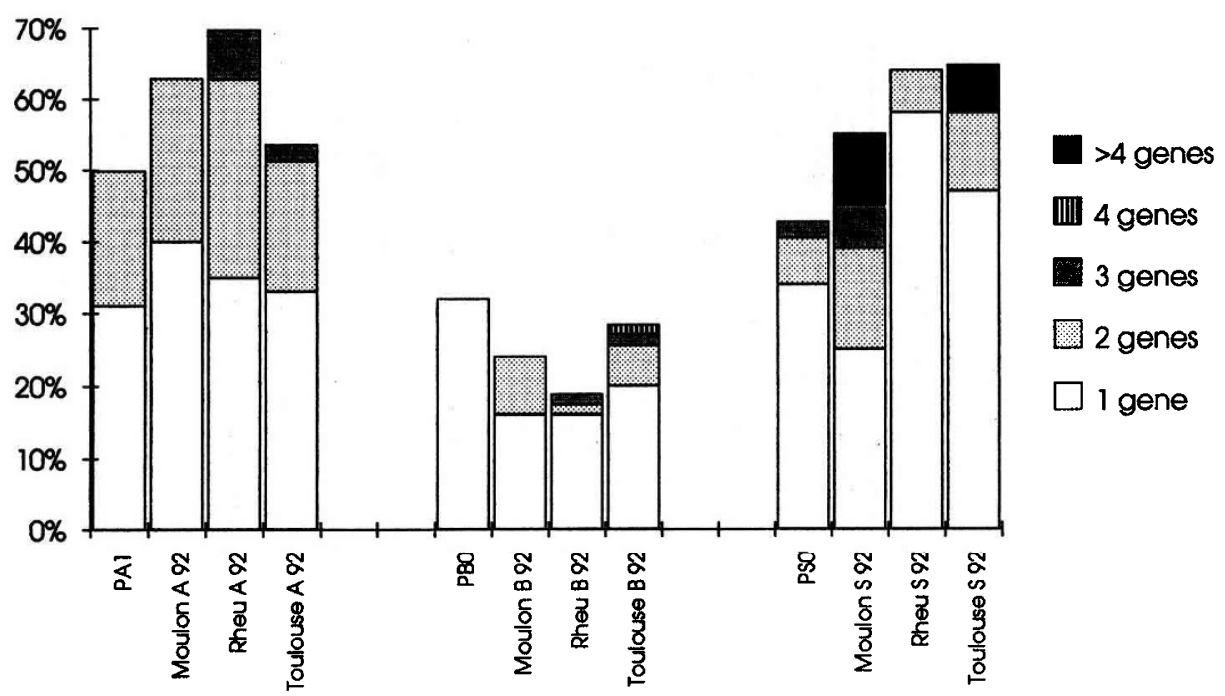

Fig 4. Postulated frequencies of the combinations of resistance genes to Erysiphe graminis f sp tritici in 12 wheat populations, initial populations and populations grown for $8 \mathrm{yr}$ at Le Moulon, Le Rheu and Toulouse.

after 8 yr of multiplication showed an increase in the frequency of plants carrying a combination of several specific resistance genes. In 2 populations of pool $\mathrm{S}$, complex combinations were selected.

\section{Evolution of adult plant resistance}

ANOVA of powdery mildew severity in populations harvested in 1990 showed a highly significant 'population' effect in both assessments. In the first one, pool A was distinguishable from pools $\mathrm{B}$ and $\mathrm{S}$ because of its greater resistance: a Student-Newman-Keuls test $(P<5 \%)$ put all the populations of pool A in one group, whereas populations of pools B and $\mathrm{S}$ were distributed into 2 groups in which powdery mildew was more severe. In the second assessment, the same test revealed 3 overlapping groups. Differences that had appeared at the first assessment were no longer distinct. Nevertheless, the most resistant group was composed of 2 populations of pool A (Le Rheu and Le Moulon).

For pools B and S, the resistance of the initial population was compared with the mean resistance level of the 3 populations harvested in 1990 using the contrast method. There was a significant decrease in resistance $(P<5 \%)$ in pool B at the first assessment. In pool $\mathrm{S}$, a mean increase in resistance, $(P<5 \%)$ appeared at the second assessment. 


\section{Relationship between specific susceptibility and adult plant susceptibility}

For each population, the frequency of susceptible plants was plotted against the 2 assessments of powdery mildew severity observed at the adult stage (fig 5). For the first assessment, the populations of the autogamous pools A and B fitted perfectly on a line with a positive slope $\left(r^{2} \leqslant 0.96\right)$. The populations of pool $\mathrm{S}$ were clearly distinguishable. For these, in spite of the high frequency of plants carrying specific resistance genes, adult plant resistance was poor, except for the Le Moulon population. For the second field assessment of the populations of the 2 autogamous pools, the linear relationship between specific susceptibility and adult plant susceptibility was maintained, but the closeness of fit was not as good $\left(r^{2} \leqslant 0.64\right)$.
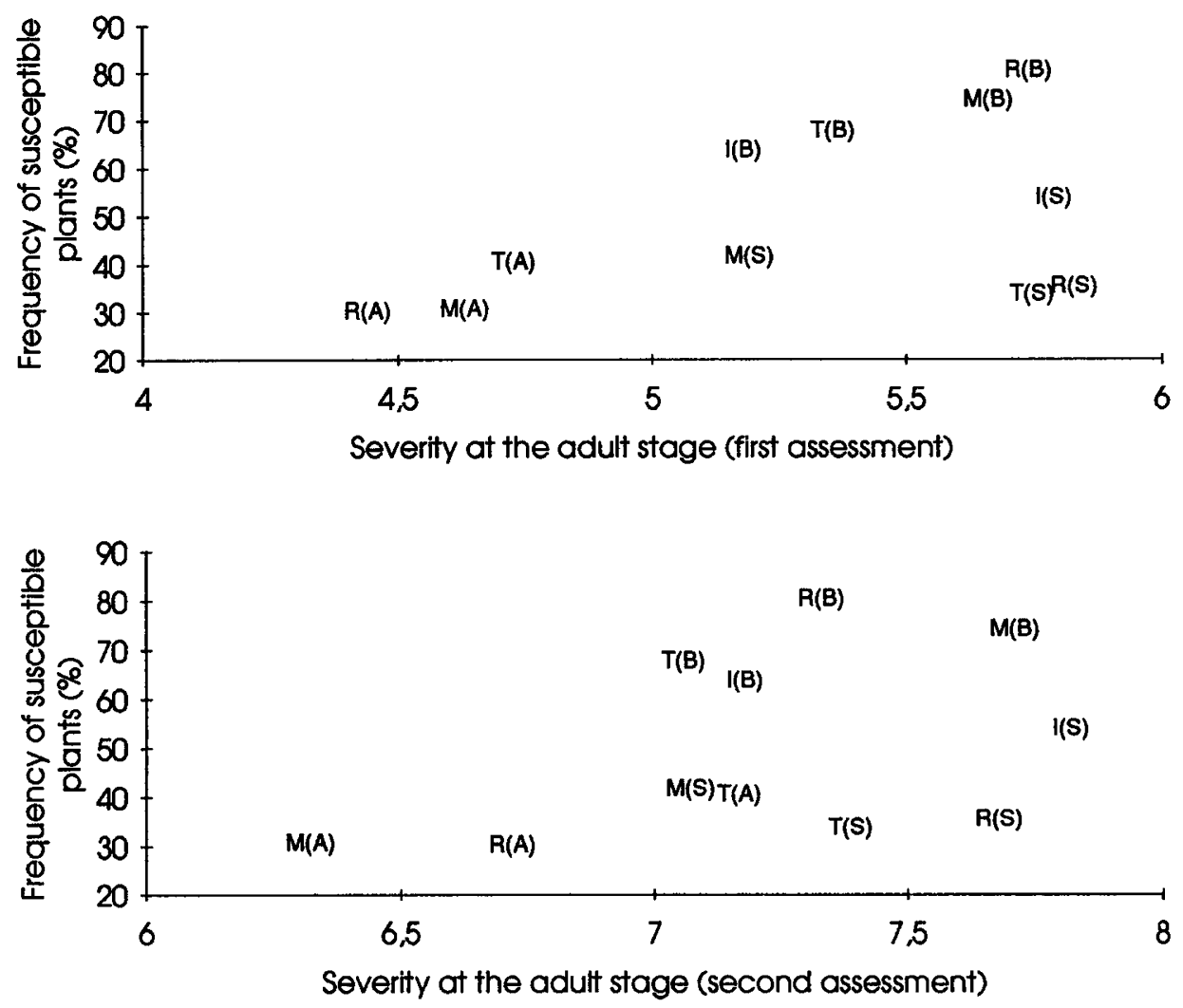

Fig 5. Relationship between adult-plant powdery mildew susceptibility and the susceptible plant frequency determined from seedling tests in wheat populations. Different generations were used for adult plants (1990) and for seedlings (1992). R: Le Rheu; M: Le Moulon; T: Toulouse; I: initial populations. The letter in parentheses indicates the origin A, B or S. First assessment in May 1991; second assessment in June 1991. 


\section{DISCUSSION}

The characteristics of the pathogen populations in the 3 sites were different. Selection pressure due to parasites was low in Toulouse, high in Le Rheu and intermediate in Le Moulon. The pathogen population in Le Rheu was very stable from one year to the next and the presence of numerous differential varieties showing a high infection rate (fig 3) indicates the population's abundance of virulence genes, associated in multivirulent strains. In contrast, the Toulouse pathogen population evolved rapidly. It was in this population that we found the greatest interactions between years and varieties and between dates and varieties (results not shown). Furthermore, the small number of strongly infected differential varieties (fig 3) suggested that the strains present in Toulouse were mono- or oligovirulent. Selection pressures due to parasites in Le Rheu and Toulouse therefore represented 2 contrasted situations. Climatic factors were probably the cause of this situation. Conditions in Le Rheu favoured the development of this parasitic fungi and thus the selection pressure that it exerted each year was considerable. The varieties most cultivated in the region are multiresistant. In fact, the Apollo variety has the 3 genes $P m 2, P m 4 b$ and $P m 8$ (McIntosh, 1988). Soissons probably has a complex resistance but it does not seem to bear genes which are currently known (Doussinault, personal communication). The multivirulent fungi strains for these genes have a better selective value than monovirulent strains and are in competition with the latter. Each year, these complex strains must be rapidly selected. Therefore, the pathogen population must be stable during each season and from one year to the next. In contrast, the climate in Toulouse does not allow major powdery mildew attacks. The pathogen population is not subjected either to inter-strain competition or to selection under the effect of very resistant varieties. Its composition in virulence genes remains simple, but drift and migration may constantly modify it. Similarly, differences in stability of parasite populations have been found between certain regions of Spain by Molina-Cano et al (1992) for $E$ graminis $\mathrm{f}$ sp hordei.

It is difficult to link the evolution of the frequencies of specific resistances in wheat populations to the spectrum of virulence genes of the pathogen populations in the different sites. Plants carrying resistance genes corresponding to rare virulence genes in the pathogen are believed to have a better selection value. However, the types of evolution which we observed contradict this prediction. Genes that have undergone the greatest increase in frequency correspond to virulence genes which are very frequent in the pathogen. Two models are possible to explain these findings.

Firstly, the spectrum of virulence genes found in the pathogen population is not representative of the region. The spores trapped near a population (PA, PB or PS) reflect the composition of the pathogen population which has succeeded in developing. Since the differential varieties were attacked with the same severity no matter which host population they were placed beside (results of the Anova are not presented), this hypothesis alone cannot explain the results.

Secondly, if certain virulence genes reduce the selection value of the fungi, the plants with the corresponding resistance gene are attacked only by strains which are not very aggressive and the disease is delayed. In this context, the resistance, even overcome, is able to provide a selective advantage. In this model, certain specific resistance genes provide the plant with partial but durable resistance. Such 
a situation has been described by Kearney and Staskawicz (1990) for Capsicum annuum - Xanthomonas campestris.

The relationship between the frequencies of specific resistance genes and virulence genes also depends on the differences in evolution of the specific resistance genes in the 3 populations $\mathrm{A}, \mathrm{B}$ and $\mathrm{S}$ multiplied on each site. The selection forces exerted by the pathogen did not lead to a parallel evolution of the populations multiplied on the same site. In fact, it seems that the evolution observed depends more on the initial genetic context than on the selection pressures at stake.

The relationship between specific susceptibility and adult susceptibility is very good for populations of the autogamous pools. Allogamous pool S stands out with a relatively low frequency of plants without resistance genes and a high incidence of disease. Pool B, with the highest specific susceptibility level, had a better performance in the field than pool S. General resistance systems are perhaps present. Pool A is very resistant in the field and could combine both mechanisms, specific resistance and general resistance.

The distinctive behaviour of pool S compared with the 2 autogamous pools has also been described for other traits (David, 1992). It can be supposed that the major selection forces for this allogamous pool are not the same as those acting on the autogamous pools. Furthermore, harvesting male sterile spikes requires human intervention and thus a subconscious selection which interferes with natural selection. Heterozygosity and the recombination rate also differentiate pool $\mathrm{S}$ from the 2 others. The favourable epistatic relations are less easily maintained and selected. On the other hand, the positive effect of recombination is illustrated by the creation of multiresistant plants (fig 4). For pool S, it seems that resistance in the field is linked more to the frequency of multiresistant plants (fig 4 and 5) than to the frequency of plants without resistance genes.

\section{CONCLUSION}

The selection pressure caused by the pathogen is variable according to time and place. Populations differ in terms of their composition of specific resistance genes and also show a variable level of adult resistance. Only one resistance gene seems to have disappeared $(P m 3 b)$ during the $8 \mathrm{yr}$ of natural selection. The other genes have kept or increased in frequency. With the creation of multiresistant plants, overall genetic variability in populations for resistance to powdery mildew is greater in the present populations than in the initial populations. Only populations PB have not undergone any increase in their resistance to powdery mildew. This could be due to the low frequencies of resistance in the initial population or interaction with the evolution of other traits subjected to stronger selection pressures. As a comparison, the improvement in resistance to Rhynchosporium secalis in barley (Allard, 1990) began only about $15 \mathrm{yr}$ after the beginning of the experiment. Generally, and especially in autogamous pools, the different traits do not evolve independently of one another and only global methods are appropriate for managing the variability of these populations. In the present populations, it seems that variability has been correctly maintained for genes involved in adaptation to the physical environment and for resistance to diseases (by extrapolating the results obtained on powdery mildew), while problems arise for conserving genes poorly adapted to interindividual 
competition. However it is necessary to maintain these genes for use in breeding programmes. Measures to stop the disappearance of dwarfing genes are in the process of being evaluated.

\section{ACKNOWLEDGMENTS}

This work was financed by the Direction Générale de l'Enseignement et la Recherche of the Ministère de l'Agriculture, the Bureau des Ressources Génétiques and the Institut National de la Recherche Agronomique. We would particularly like to thank A Gallais and $\mathrm{PH}$ Gouyon as well as JP Henry for initiating the project on the dynamic conservation of genetic variability in winter wheat. We would also like to thank G Doussinault and $\mathrm{H}$ Goyeau for their help and advice, and C Young for translating the article into English.

\section{REFERENCES}

Allard RW (1988) Genetic changes associated with the evolution of adaptedness in cultivated plants and their wild progenitors. $J$ Hered $79,225-238$

Allard RW (1990) The genetics of host - pathogen coevolution: implications for genetic resource conservation. $J$ Hered $81,1-6$

Andrivon D, de Vallavieille-Pope C (1993) Racial diversity and complexity in regional populations of Erysiphe graminis f sp hordei in France over a 5-year period. Plant Pathol 42, 443-464

Austin RB, Ford MA, Morgan CL (1989) Genetic improvement in the yield of winter wheat: a further evaluation. J Agric Sci Camb 112, 295-301

Charnov EL (1982) The Theory of Sex Allocation. Princeton University Press, Princeton, New Jersey

David JL (1992) Approche méthodologique d'une gestion dynamique des ressources génétiques chez le blé tendre (Triticum aestivum L). Thèse de l'Institut National Agronomique Paris-Grignon

David JL, Pham JL (1993) Rapid changes in pollen production in experimental outcrossing populations of wheat. J Evol Biol 6, 659-676

David JL, Savy Y, Trottet M, Pichon M (1992) Méthode de gestion dynamique de la variabilité génétique. Exemple d'un réseau expérimental de populations composites de blé tendre. In: Complexes d'espèces, flux de gènes et ressources génétiques. BRG, Paris, 337-350

Flor HH (1955) Host parasite interaction in flax rust, its genetics and other implications. Phythopathology 45, 680-685

Gallais A, Duval H, Garnier P, Charcosset A (1992) Un exemple de gestion des ressources génétiques en vue de la sélection. In: Complexes d'espèces, flux de gènes et ressources génétiques. BRG, Paris, 477-490

Goldringer I, Brabant P, Kempton RA (1994) Adjustment for competition between genotypes in single row-plot trials of winter wheat (Triticum aestivum). Plant Breeding (in press)

Henry JP, Pontis C, David J, Gouyon PH (1991) An experiment on dynamic conservation of genetic resources with metapopulations. In: Species conservation: a population-biological approach (Seitz A, Loeschcke V, eds). Birkhaäser, Basel, 185-198 
Hockett EA, Eslick RF, Qualset CO, Dubbs AL, Stewart VR (1983) Effects of natural selection in advanced generations in barley composite cross II. Crop Sci 23, $752-756$

Kato K, Yokoyama H (1992) Geographical variation in heading characters among wheat landraces, Triticum aestivum $\mathrm{L}$, and its implication for their adaptability. Theor Appl Genet 84, 259-265

Kearney B, Staskawicz J (1990) Widespread distribution and fitness contribution of Xanthomonas campestris avirulence gene avrBs2. Nature 346, 385-386

Khalifa MA, Qualset CO (1975) Intergenotypic competition between tall and dwarf wheats II. In hybrid bulks. Crop Sci 15, 640-644

Limpert E (1985) Ursachen unterschiedlicher Zusammensetzung des Gerstenmehltaus, Erysiphe graminis DC f sp hordei Marchal, und deren Bedeutung für Züchtung und Anbau von Gerste in Europa. Thèse université Technique de Munich

McIntosh RA (1988) Catalogue of gene symbols for wheat. In: Proceedings of the Seventh International Wheat Genetics Symposium (Miller TE, Koebner RMD eds), Cambridge, 13-19 July, Institute of Plant Science Research Cambridge, Vol 2, 12251323

McIntosh RA, Hart GE, Gale MD (1989) Catalogue of gene symbols for wheat. (1989 supplement). Annu Wheat Newsl 35, 231-241

McIntosh RA, Hart GE, Gale MD (1990) Catalogue of gene symbols for wheat. (1990 supplement). Cereal Res Comm 18, 141-157

Mitchell-Olds T (1992) Does environmental variation maintain genetic variation? A question of scale. Tree 7, 397-398

Molina-Cano JL, Montoya JL, Echarte J, Royo C, Serra J, Marin-Sanchez JP (1992) Effectiveness of twenty-four barley resistance genes against powdery mildew (Erysiphe graminis DC f sp hordei Em Marchal) in Spain. Plant Breed 109, 40-45 Nevo E, Beiles A (1992) Amino-acid resources in wild progenitors of wheats, Triticum diccocoides, in Israel. Polymorphism and predictability by ecology and isozymes. Plant Breeding 108, 190-201

Oosterom Van EJ, Acevedo E (1992) Adaptation of barley (Hordeum vulgare L) to harsh Mediterranean environments. I. Morphological traits. Euphytica 62, 1-14

Pernès J (1984) Gestion des ressources génétiques des plantes. Vol 2. Technique et documentation, Lavoisier, Paris

Picard E (1984) Contribution à l'étude de l'hérédité et de l'utilisation en sélection de l'haplodiploïdisation par androgenèse in vitro chez une céréale autogame Triticum aestivum L Thèse d'état $\mathrm{n}^{\circ} 2902$. Université Paris Sud, Orsay

Pinthus MJ, Gale MD (1990) The effects of 'gibberellin-insensitive' dwarfing alleles in wheat on grain yield and protein content. Theor Appl Genet 79, 108-112

Pontis C (1992) Utilisation de marqueurs génétiques pour le suivi de la variabilité de 3 composites de blé tendre d'hiver (Triticum aestivum L) menées en gestion dynamique. Thèse de l'Institut National Agronomique Paris-Grignon

Scott PR, Benedikz PW, Jones HG, Ford MA (1985) Some effects of canopy structure and microclimate on infection of tall and short wheats by Septoria nodorum. Plant Pathol 34, 578-593

Thomas G, Rousset M, Pichon M, Trottet M, Doussinault G, Picard E (1991) Méthodologie de l'amélioration du blé tendre (Triticum aestivum L). I. Création 
par croisements et analyse d'une population artificielle à 16 parents, base de cette étude méthodologique. agronomie 11, 359-368

Trottet M (1988) Use of genic male sterility for breeding wheat lines resistant to Leptosphaeria nodorum Müller: results of first selection cycle and prospect. In: Proceedings of the Seventh International Wheat Genetics Symposium (Miller TE, Koebner RMD eds), Cambridge, 13-19 July, Institute of Plant Science Research Cambridge, Vol 2, 1199-1202

Weir BS, Allard RW, Kahler AL (1974) Further analysis of a complex allozyme polymorphism in a barley population. Genetics 78, 911-919 


\section{ANNEX I}

Virulence spectra of the 9 test isolates of Erysiphe graminis $\mathrm{f}$ sp tritici for 12 genes. The spectra of the isolates were determined from numerous tests consisted of individual infection of differential hosts. The tests used segments of their primary leaf.

\begin{tabular}{cccccccccccccc}
\hline Isolate & \multicolumn{10}{c}{ Virulence gene } \\
\cline { 2 - 12 } & \cline { 2 - 7 } & Pml & Pm2 & Pm3a & Pm3b & Pm3c & Pm4a & Pm4b & Pm5 & Pm6 & Pm8 & Mli & Mia \\
\hline 1 & + & + & + & + & + & - & - & + & + & - & + & + \\
2 & + & + & - & - & - & $?$ & + & - & + & - & - & - \\
3 & - & + & - & $?$ & + & + & + & + & $?$ & + & + & + \\
4 & + & - & - & - & + & + & + & + & $?$ & + & + & + \\
5 & + & + & - & $?$ & + & + & + & + & + & + & $?$ & + \\
6 & + & + & - & - & - & + & + & + & + & $?$ & - & - \\
7 & + & + & - & - & + & - & - & + & $?$ & + & + & + \\
8 & + & + & - & + & + & + & + & - & $?$ & + & + & - \\
9 & + & + & $?$ & + & + & - & - & + & + & - & + & + \\
\hline
\end{tabular}

+ virulence gene present in isolate; - avirulence gene present in isolate; ? indetermination (non-repeatable or intermediate reaction).

To reveal the presence of the 12 resistance genes, we may have 2 isolates with the following spectra for each pair of genes:

\begin{tabular}{ccc}
\hline Isolate & \multicolumn{2}{c}{ Virulence gene } \\
\cline { 2 - 3 } & $\mathrm{a}$ & $\mathrm{b}$ \\
\hline $\mathrm{i}$ & + & - \\
$\mathrm{j}$ & - & + \\
\hline
\end{tabular}

The presence of 2 genes is indissociable, when the reaction of all isolates give the following spectra:

\begin{tabular}{lcc}
\hline Isolate & \multicolumn{2}{c}{ Virulence gene } \\
\cline { 2 - 3 } & $\mathrm{a}$ & $\mathrm{b}$ \\
\hline $\mathrm{i}$ & - & - \\
$\mathrm{j}$ & - & - \\
\hline
\end{tabular}

